\title{
Japanese Family with a Deficiency of Lecithin: Cholesterol Acyltransferase (LCAT)
}

\author{
Michitaka NaIto, Eiichi MaedA*, Gen Yoshino**, Masato Kasuga*, Akihisa Iguchi and Fumio KuzuYA***
}

We present findings in the ninth known Japanese family with lecithin : cholesterol acyltransferase (LCAT) deficiency. A 54-year-old man (proband) and his 58-year-old brother presented with corneal opacity. Both subjects showed a marked decrease in serum high density lipoprotein (HDL)cholesterol and in the cholesteryl ester ratio. Although apo A-I and A-II were low, apo E tended to be high. Serum LCAT activity and mass were not detectable. Urinary examination showed microhematuria or proteinuria. Renal function was normal and no anemia was demonstrated, but blood smears showed poikilocytosis with target cells. The serum LCAT activity of the proband's three sons, obligate heterozygotes of LCAT deficiency, was about one-half the normal level, and HDL-cholesterol and apo A-I levels were low normal.

(Internal Medicine 33: 677-682, 1994)

Key words: high density lipoprotein, cholesteryl ester ratio, hematuria, proteinuria, poikilocytosis, heterozygote

\section{Introduction}

Lecithin : cholesterol acyltransferase (LCAT; EC 2.3.1.43) is a glycoprotein synthesized by hepatocytes and secreted into the plasma. It forms a complex with HDL particles and catalyzes the formation of cholesteryl esters and lysolecithin by the preferential translocation of unsaturated sn-2 fatty acids from lecithin to the 3ß-hydroxy group of cholesterol. Cholesteryl esters that are formed in this enzymatic reaction are subsequently transferred into the hydrophobic core of HDL particles $(1,2)$. Consequently, LCAT brings about the maturation of the HDL particles; it mediates an essential step in the reverse cholesterol transport process whereby excess cellular cholesterol is transferred to the liver, from which it can leave the body by bile acid formation or direct secretion into the bile.

Familial deficiency of LCAT is an autosomal recessive disorder characterized by abnormalities of all plasma lipoprotein classes and by abnormal deposition of free cholesterol in tissues. The responsible gene resides on the long arm of chromosome 16 (3). Clinically, familial LCAT deficiency frequently presents with corneal opacities, normochromic anemia, and proteinuria. Since the first description by Norum and Gjone in 1967 (4), familial LCAT deficiency has been reported in more than 30 families worldwide (5). Most of the cases are from European countries, especially Scandinavia. At least eight Japanese families with LCAT deficiency have been reported since Iwamoto et al (6) reported the first case from Japan in 1978.

This paper describes the ninth Japanese family with LCAT deficiency, the members were two homozygotes and three obligate heterozygotes. The present work was presented at the annual meeting of the Japan Atherosclerosis Society held in Fukuoka on May 21, 1993 (7).

\section{Methods}

\section{Lipoprotein analysis}

Blood was drawn from each subject after an overnight fast. The lipoprotein fractions were isolated serially by ultracentrifugation, according to the procedure described by Hatch and Lees (8). The concentrations of total cholesterol (TC), free cholesterol (FC), triglycerides (TG), and phospholipids (PL) were determined by routine enzymatic methods. HDL-cholesterol (HDL-C) was determined by the heparin calcium precipitation method. Apolipoproteins A-I, AII, B, C-II, C-III, and E were measured by TIA methods.

From the Department of Geriatrics, Nagoya University School of Medicine, Nagoya, *the Second Department of Internal Medicine. Kobe University School of Medicine, Kobe, **the Department of Laboratory Medicine, Toho University School of Medicine, Tokyo and ***the Department of Internal Medicine, Nakatsugawa Municipal Hospital, Nakatsugawa

Received for publication April 25, 1994; Accepted for publication June 24, 1994

Reprint requests should be addressed to Dr. Michitaka Naito, the Department of Geriatrics, Nagoya University School of Medicine, 65 Tsuruma-cho, Showaku, Nagoya 466 


\section{NAITO et al}

Phospholipids extracted from serum were separated by thinlayer chromatography on a silica gel-sintered stick with chloroform and detected by a flame ionization detector $(9,10)$. Lipoprotein (a) was measured by ELISA. Agarose gel electrophoresis was carried out as described by Noble (11) and lipoprotein $\mathrm{X}$ was examined as described by Glomset et al (12). Electron microscopy of HDL particles was performed using Formvar-coated grids and 1\% sodium phosphotungstate as a negative stain (13). Serum LCAT activity was measured by a sensitive artificial substrate method, using proteoliposomes containing apo A-I as a substrate (14). LCAT mass was determined by radioimmunoassay, using rabbit anti-human LCAT antibody (15).

\section{Case Histories and Results}

Case 1 (O.T., the proband), a 54-year-old Japanese male, was born in 1938. When he was 24 years old, he lost his right forearm in an accident. In 1992, he visited our clinic with complaints of gastrointestinal trouble; because of corneal opacities, he was suspected of having LCAT deficiency. Physical examination revealed no clinical abnormalities except for corneal opacities with corneal rings (Fig. 1) and a missing right forearm. His corneal opacities had been noticed from childhood.

Laboratory findings are shown in Table 1 . Urinary examination showed microscopic hematuria and occasional small round cells and hyaline casts in the sediment, but no proteinuria. Serum urea nitrogen and creatinine were within normal limits. No anemia was demonstrated, but the blood smear showed poikilocytosis with target cells (Fig. 2). In vitamin A fractions, serum retinol was normal, but retinyl palmitate was increased. Serum concentrations of vitamin $\mathrm{E}$ fractions were normal. There was no significant decrease of serum haptoglobin whose gene position (16q22) is close to that of LCAT, and the phenotype was 2-2.

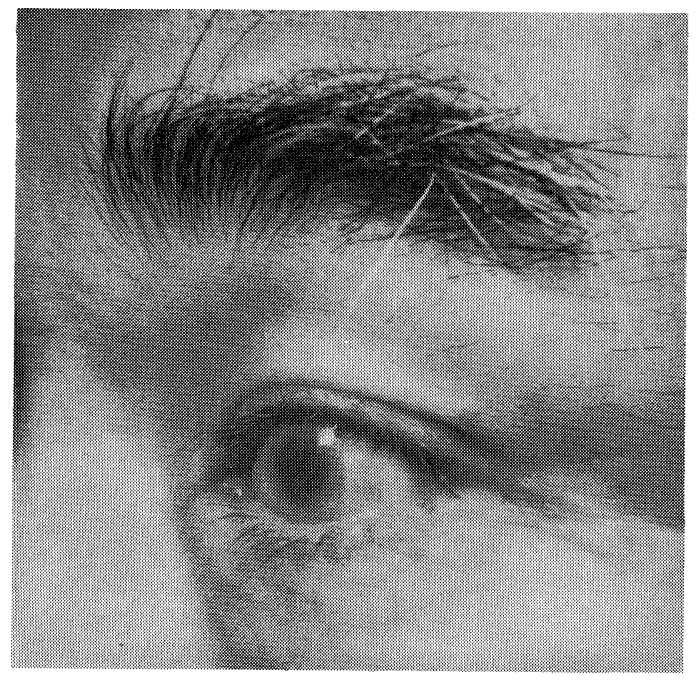

Fig. 1. Appearance of cornea in Case 1 (proband). Diffuse cloudiness of the cornea and conspicuous annular ring are seen.
Serum TC was $135 \mathrm{mg} / \mathrm{dl}$, the cholesteryl ester ratio (CE) was $9 \%$, and serum HDL-C was $8.9 \mathrm{mg} / \mathrm{dl}$ (Table 2). Although apo A-I and A-II were low, apo E tended to be high. Serum phospholipid analysis demonstrated $94.6 \%$ lecithin and 5.4\% sphingomyelin, but no lysolecithin was detectable. Serum LCAT activity and mass were not detectable, suggesting that the subject is a homozygote for LCAT deficiency. The results of agarose gel electrophoresis are shown in Fig. 3. Lipoprotein $\mathrm{X}$ was demonstrated (Fig. 4). LDL was rich in TG and PL (Table

Table 1. Laboratory Findings of Case 1 (Proband)

\begin{tabular}{|c|c|c|c|}
\hline \multicolumn{2}{|l|}{ Serum chemistry } & \multicolumn{2}{|l|}{ Vitamin A fractions } \\
\hline Total protein & $6.5 \mathrm{~g} / \mathrm{dl}$ & Retinol & $46.1 \mu \mathrm{g} / \mathrm{dl}$ \\
\hline Albumin & $4.18 \mathrm{~g} / \mathrm{dl}$ & Retinyl palmitate & $17.8 \mu \mathrm{g} / \mathrm{dl}$ \\
\hline$\alpha_{1}$-globulin & $0.25 \mathrm{~g} / \mathrm{dl}$ & \multicolumn{2}{|l|}{ Vitamin E fractions } \\
\hline$\alpha_{2}$-globulin & $0.49 \mathrm{~g} / \mathrm{dl}$ & $\alpha$-tocopherol & $0.87 \mathrm{mg} / \mathrm{dl}$ \\
\hline B-globulin & $0.55 \mathrm{~g} / \mathrm{dl}$ & B-tocopherol & $0.02 \mathrm{mg} / \mathrm{dl}$ \\
\hline$\gamma$-globulin & $1.04 \mathrm{~g} / \mathrm{dl}$ & $\gamma$-tocopherol & $0.16 \mathrm{mg} / \mathrm{dl}$ \\
\hline Thymol turbidity test & $4.4 \mathrm{U}$ & $\delta$-tocopherol & $<0.01 \mathrm{mg} / \mathrm{dl}$ \\
\hline Total bilirubin & $1.8 \mathrm{mg} / \mathrm{dl}$ & \multicolumn{2}{|l|}{ Complate blood count } \\
\hline Aspartate aminotransferas & e $23 \mathrm{IU} / 1$ & Red blood cells & $429 \times 10^{4} / \mu 1$ \\
\hline Alanine aminotransferase & $31 \mathrm{IU} / 1$ & Hemoglobin & $13.7 \mathrm{~g} / \mathrm{dl}$ \\
\hline Lactate dehydrogenase & $327 \mathrm{IU} / 1$ & Hematocrit & $42.2 \%$ \\
\hline Alkaline phosphatase & $158 \mathrm{IU} / 1$ & Mean corpuscular volume & $98 \mathrm{fl}$ \\
\hline Cholinesterase & $268 \mathrm{IU} / 1$ & \multicolumn{2}{|l|}{ Mean corpuscular } \\
\hline$\gamma$-glutamyl transpeptidase & $32 \mathrm{IU} / 1$ & hemoglobin & $31.9 \mathrm{pg}$ \\
\hline Creatine kinase & $73 \mathrm{IU} / 1$ & \multicolumn{2}{|c|}{ Mean corpuscular hemoglobin } \\
\hline $\mathrm{Na}$ & $137 \mathrm{mEq} / \mathrm{l}$ & concentration & 32.5 \\
\hline K & $3.9 \mathrm{mEq} / 1$ & Platelets & $18.8 \times 10^{4} / \mu \mathrm{l}$ \\
\hline $\mathrm{Cl}$ & $102 \mathrm{mEq} / \mathrm{l}$ & White blood cells & $6,200 / \mu \mathrm{l}$ \\
\hline $\mathrm{Ca}$ & $8.9 \mathrm{mg} / \mathrm{dl}$ & Urinalysis & \\
\hline $\mathrm{P}$ & $3.9 \mathrm{mg} / \mathrm{dl}$ & Protein & - \\
\hline Uric acid & $5.7 \mathrm{mg} / \mathrm{dl}$ & Sugar & - \\
\hline Urea nitrogen & $16.1 \mathrm{mg} / \mathrm{dl}$ & Blood & $2+$ \\
\hline Creatinine & $0.6 \mathrm{mg} / \mathrm{dl}$ & $\mathrm{pH}$ & 6.5 \\
\hline \multirow[t]{5}{*}{ Amylase } & $101 \mathrm{IU} / 1$ & Sediment & \\
\hline & & Red blood cells & $8-10 / F$ \\
\hline & & White blood cells & $3-4 / F$ \\
\hline & & Hyaline casts & $1 / 2-3 F$ \\
\hline & & Small round cells & $1 / 10-15 \mathrm{~F}$ \\
\hline
\end{tabular}

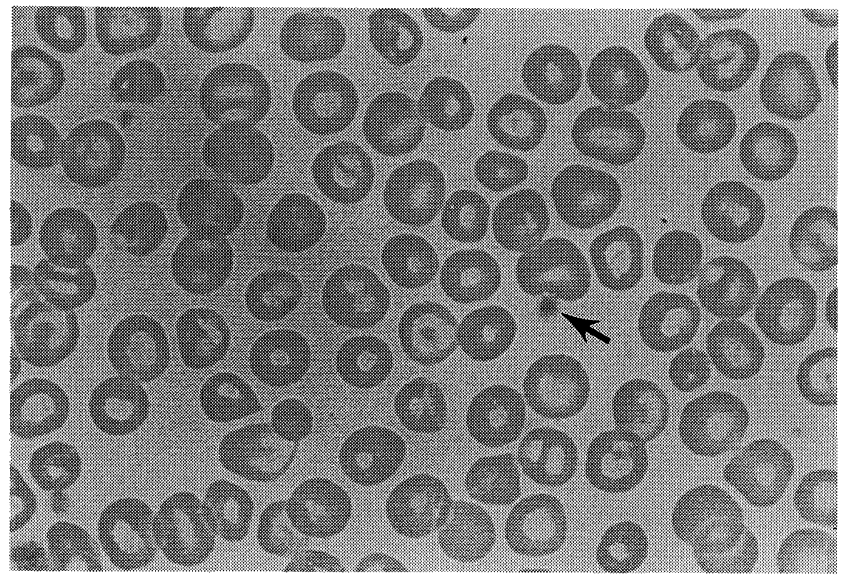

Fig. 2. Poikilocytosis with target cells in the peripheral blood smear from Case 1. A giant platelet is also seen (arrow). (May-Grünwald-Giemsa stain, $\times 1,000)$. 


\section{A Family with LCAT Deficiency}

Table 2. Lipid Profile of Six Family Members Investigated

\begin{tabular}{|c|c|c|c|c|c|c|c|c|c|c|c|c|c|c|c|c|}
\hline \multirow[t]{2}{*}{ Case } & \multirow[t]{2}{*}{ Sex } & \multirow{2}{*}{$\begin{array}{c}\text { Age } \\
\text { (years) }\end{array}$} & \multirow{2}{*}{$\begin{array}{c}\mathrm{TC} \\
(\mathrm{mg} / \mathrm{dl})\end{array}$} & \multirow{2}{*}{$\begin{array}{c}\mathrm{FC} \\
(\mathrm{mg} / \mathrm{dl})\end{array}$} & \multirow{2}{*}{$\begin{array}{l}\text { CE } \\
(\%)\end{array}$} & \multirow{2}{*}{$\begin{array}{l}\text { HDL-C } \\
(\mathrm{mg} / \mathrm{dl})\end{array}$} & \multirow{2}{*}{$\begin{array}{c}\mathrm{TG} \\
(\mathrm{mg} / \mathrm{dl})\end{array}$} & \multirow{2}{*}{$\begin{array}{l}\mathrm{LP}(\mathrm{a}) \\
(\mathrm{mg} / \mathrm{dl})\end{array}$} & \multicolumn{6}{|c|}{ Apoproteins (mg/dl) } & \multirow{2}{*}{$\begin{array}{l}\text { LCAT } \\
\text { ac- } \\
\text { tivity } \\
\text { (ng/ } \\
\text { h/ml) }\end{array}$} & \multirow{2}{*}{$\begin{array}{c}\text { LCAT } \\
\text { mass } \\
(\mu \mathrm{g} / \\
\mathrm{ml})\end{array}$} \\
\hline & & & & & & & & & A-I & A-II & B & C-II & C-III & $\mathrm{E}$ & & \\
\hline 1 & M & 54 & 135 & 123 & 9 & 8.9 & 192 & 1 & 53 & 14 & 69 & 2.7 & 5.9 & 11.0 & ND & ND \\
\hline 2 & M & 58 & 115 & 99 & 14 & 6.9 & 152 & 1 & 55 & 10 & 60 & 3.1 & 4.1 & 10.0 & ND & ND \\
\hline 3 & M & 24 & 142 & 35 & 75 & 31.8 & 96 & - & 92 & 29 & 69 & 1.6 & 4.6 & 2.4 & 375 & - \\
\hline 4 & M & 23 & 149 & 36 & 76 & 32.7 & 111 & - & 99 & 32 & 75 & 3.1 & 6.3 & 2.8 & 467 & - \\
\hline 5 & M & 18 & 150 & 36 & 76 & 36.4 & 123 & - & 113 & 34 & 74 & 2.7 & 7.7 & 4.5 & 477 & - \\
\hline 6 & $\mathrm{~F}$ & 49 & 167 & 37 & 78 & 54.5 & 40 & - & 128 & 29 & 61 & 1.5 & 5.2 & 3.2 & 653 & - \\
\hline
\end{tabular}

TC: total cholesterol, FC: free cholesterol, CE: cholesteryl ester ratio, HDL-C: high density lipoprotein-cholesterol, TG: triglycerides, LP(a): lipoprotein (a), ND: not detected.

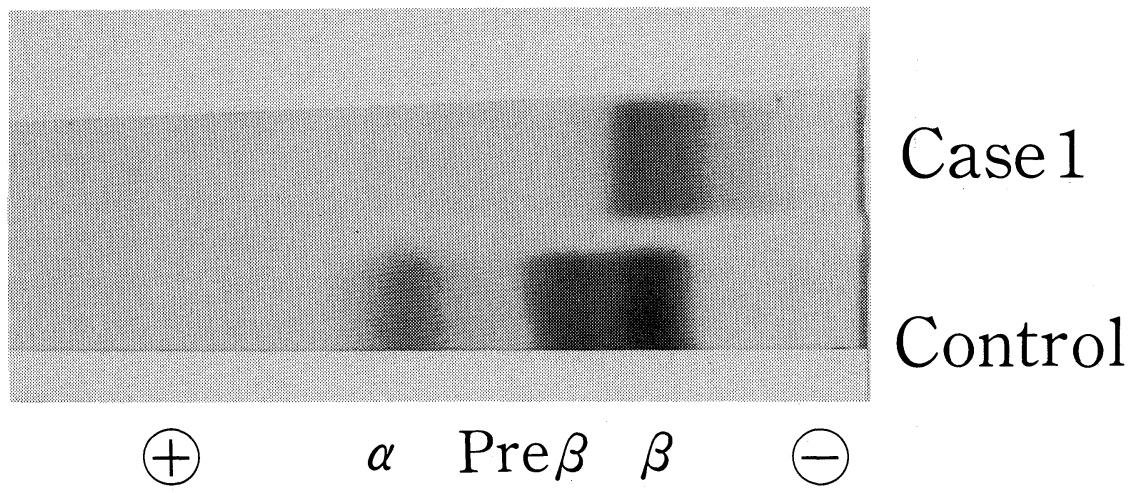

Fig. 3. Agarose gel electrophoresis of lipoprotein from Case 1 (upper) and from a normal subject (lower).

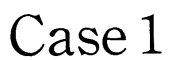

Negative control

\section{Positive control}

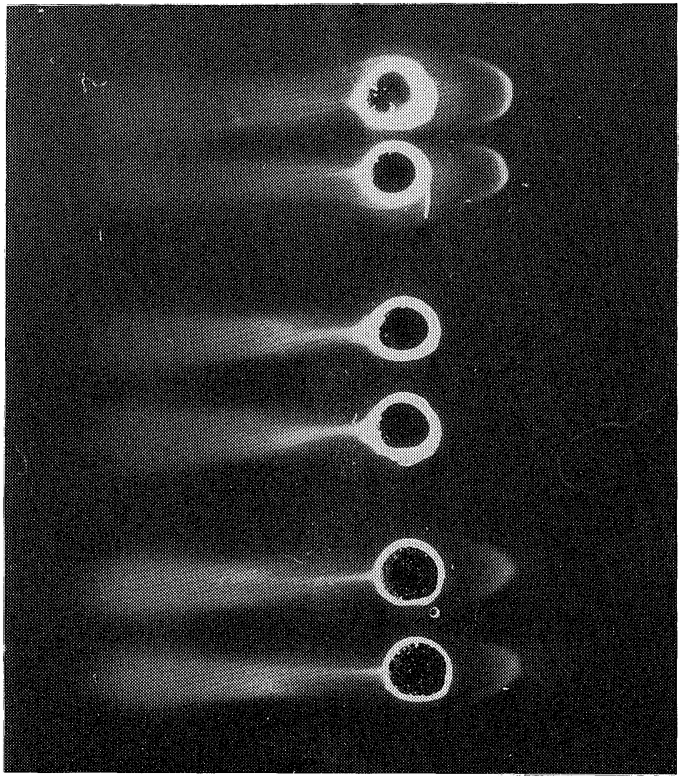

Fig. 4. Demonstration of lipoprotein $\mathrm{X}$ in Case 1 . 
Table 3. Lipoprotein Analysis of Cases 1, 2, and 4

\begin{tabular}{rcrrr}
\hline & & Case 1 & Case 2 & Case 4 \\
\hline \multirow{4}{*}{ VLDL } & C & 32.4 & 21.3 & 16.2 \\
& TG & 133.7 & 72.0 & 72.9 \\
& PL & 54.9 & 39.6 & 15.3 \\
& & & & \\
LDL & C & 84.4 & 76.1 & 93.4 \\
& TG & 54.2 & 72.1 & 27.4 \\
& PL & 150.2 & 138.0 & 63.6 \\
& & & & \\
HDL & HDL $_{2}-\mathrm{C}$ & 15.4 & 12.2 & 21.9 \\
& $\mathrm{HDL}_{3}-\mathrm{C}$ & 2.8 & 5.4 & 17.5 \\
& $\mathrm{TG}$ & 6.1 & 7.9 & 22.4 \\
& $\mathrm{PL}$ & 66.7 & 59.4 & 86.1 \\
\hline
\end{tabular}

$(\mathrm{mg} / \mathrm{dl})$

3). $\mathrm{HDL}_{2}-\mathrm{C}$ was slightly decreased and $\mathrm{HDL}_{3}-\mathrm{C}$ was severely decreased.

Case 2 (K.T.), a 58-year-old Japanese male, is the elder brother of Case 1 (Fig. 5). At the age of 48 years, he underwent surgery because of subarachnoid hemorrhage. He has been under a physician's care due to diabetes mellitus for several years. Physical examination showed corneal opacities and rings similar to those of Case 1. Marked proteinuria was demonstrated, although the results of renal function tests were normal. Serum LCAT mass and activity were not detectable, suggesting that Case 2 was also homozygous for LCAT deficiency (Table 2). The ultracentrifugally separated HDL fraction showed rouleaux formation of discoid HDL particles (Fig. 6).

Family background. The parents of Cases 1 and 2 were first cousins who were born in Nakatsugawa City, Gifu Prefecture,
Japan (Fig. 5). The LCAT activity of the wife and three sons of Case 1 was determined (Table 2). The LCAT activity of the sons, who were all obligate heterozygotes, was low, about onehalf the normal level. The LCAT activity of the proband's wife was normal. HDL-C and apo A-I levels of the sons were low normal, between those of the homozygotes and normal (Case 6). Lipoprotein fractions of a heterozygote, Case 4, were normal, except that $\mathrm{HDL}_{2}$ - and $\mathrm{HDL}_{3}-\mathrm{Clevels}$ were low normal (Table 3).

\section{Discussion}

Several disorders that affect lipoprotein metabolism are associated with HDL deficiency and corneal opacification, including Tangier disease (16), LCAT deficiency $(4,17)$, fish eye disease $(17,18)$, apo A-I, C-III deficiency (19), apo C-III, A-I, A-IV deficiency (20), fish eye-like dyslipoproteinemia (21), and specific apo A-I variants $(22,23)$. Although the degree of corneal opacity ranges from mild cloudiness in Tangier disease to severe opacification in fish eye disease, it does not correlate with the degree of reduction of HDL. Despite the marked reduction in HDL, many of these conditions are not associated with premature atherosclerosis. There was no evidence of ischemic heart disease or other atherosclerotic disorders in the present family.

LCAT deficiency demonstrates several characteristic features $(1,2,17)$, including: (a) corneal opacities or rings present from childhood; (b) low HDL-cholesterol, apo A-I, and increased immature apoA-I, called pre apo A-I or apo A-I $\mathrm{I}_{2}$; (c) presence of lipoprotein particles forming rouleaux in LDL and HDL fractions; (d) poikilocytosis, such as target cells, caused

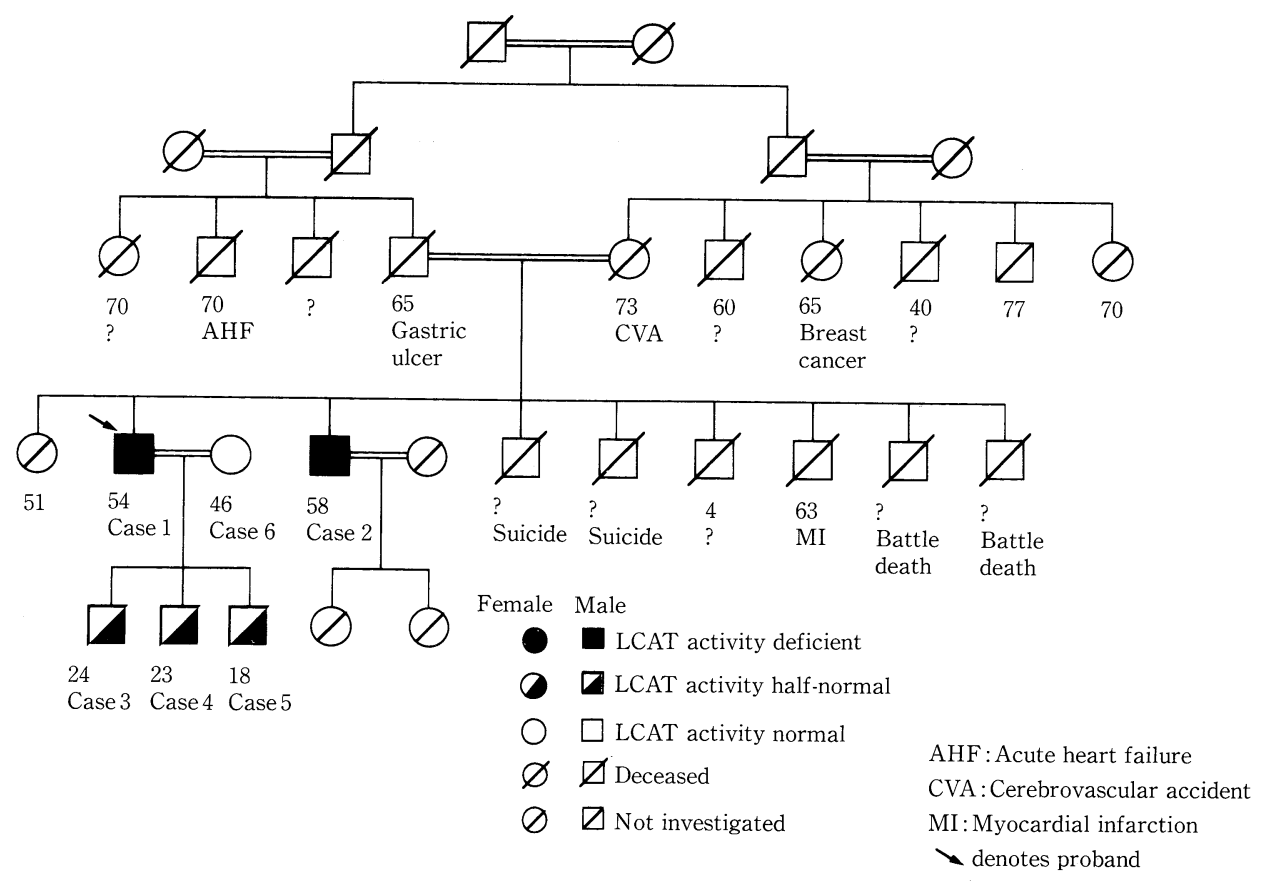

Fig. 5. Family pedigree. 


\section{A Family with LCAT Deficiency}

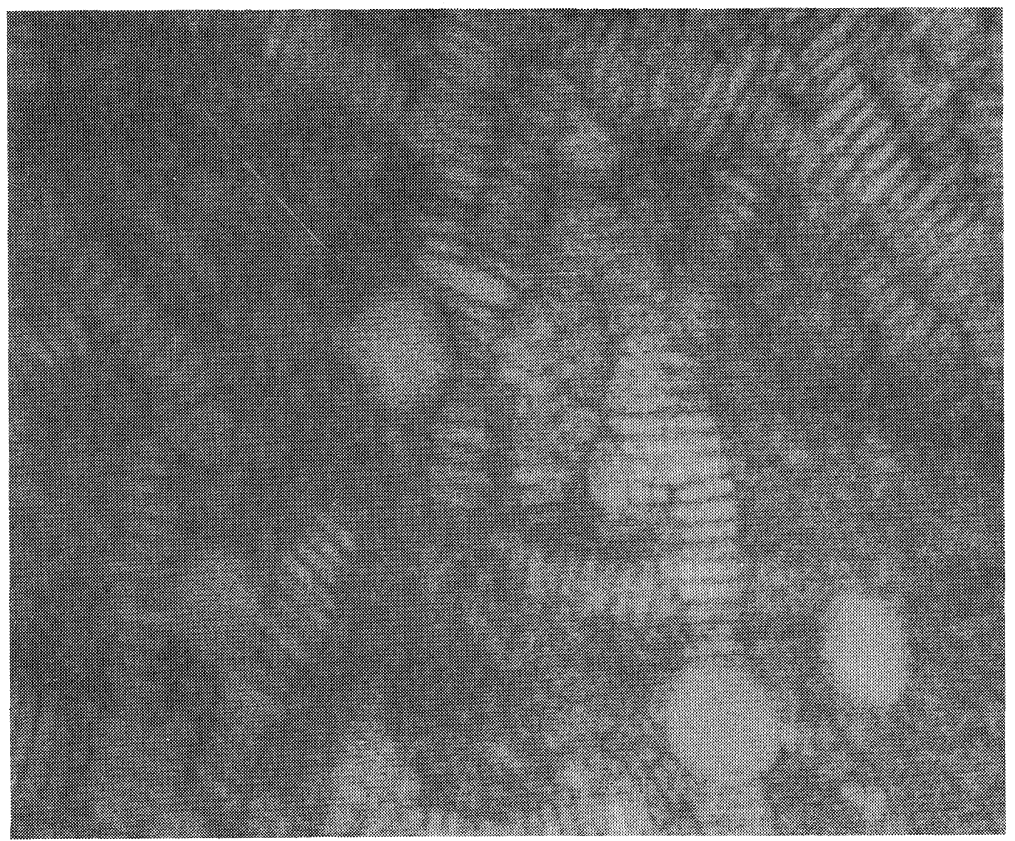

Fig. 6. Electron micrograph of HDL from Case $2(\times 300,000)$.

by membrane abnormality due to HDL dysfunction; (e) low serum cholesteryl ester ratio. These findings are observed only in homozygotes, not in heterozygotes. Proteinuria and anemia are common. Eventually, renal function deteriorates and dialysis or renal transplantation may become necessary. The present cases had normal renal function, but Case 1 showed microhematuria and Case 2 showed marked proteinuria. They are now being followed at Nakatsugawa Municipal Hospital.

At least nine independent families with LCAT deficiency have been reported from Japan, including the present family (6, 24-30). Among them, the molecular defects of four families were recently analyzed by polymerase chain reaction and subsequent direct sequencing (31-33). Their results show that distinct mutations cause differences in plasma LCAT activity and LCAT mass, leading ultimately to differential phenotypic expression of familial LCAT deficiency. The consequence of molecular defects in the LCAT gene is (a) a null allele, (b) a synthesis defect, (c) an enzyme with impaired binding to both HDL and VLDL-LDL, or (d) a functionally inactive or hypoactive enzyme $(34,35)$.

In the two homozygous cases in the present family, LCAT mass and activity were not detectable, suggesting that they are so-called null type cases. In the three heterozygotes, LCAT activity was about half of normal level. In some early cases from Japan, only serum or plasma LCAT activity was measured, but in other cases LCAT mass was also determined. Among them, a case reported by Murano et al (28) is also a null type, demonstrating almost negligible LCAT mass and activity. Gene analysis of the present family is now in progress in one of our laboratories (E. Maeda).
Acknowledgements: We thank Ms. Y. Niwa for her technical assistance.

\section{References}

1) Glomset JA. The plasma lecithin : cholesterol acyltransferase reaction. J Lipid Res 9: 155, 1968.

2) Glomset JA, Norum KR. The metabolic role of lecithin : cholesterol acyltransferase. Adv Lipid Res 2: 1, 1973.

3) McLean J, Wion K, Drayna D, Fielding C, Lawn R. Human lecithin: cholesterol acyltransferase gene sequence and sites of expression. $\mathrm{Nu}$ cleic Acid Res 14: 9387, 1986.

4) Norum KR, Gjone E. Familial plasma lecithin: cholesterol acyltransferase deficiency. Biochemical study of a new inborn error of metabolism. Scand J Clin Lab Invest 20: 2341, 1967.

5) Norum KR, Gjone E, Glomset JA. Familial lecithin : cholesterol acyltransferase deficiency, including fish eye disease. in: The Metabolic Basis of Inherited Disease, Scriver CR, Beaudet AL, Sly WS, Valle D, Eds. McGraw-Hill Inc, New York, 1989, p. 1181.

6) Iwamoto $\mathrm{A}$, Naito $\mathrm{C}$, Teramoto $\mathrm{T}$, et al. Familial lecithin : cholesterol acyltransferase deficiency complicated with unconjugated hyperbilirubinemia and peripheral neuropathy. The first reported case in the Far East. Acta Med Scand 204: 219, 1978.

7) Naito M, Kuzuya F, Maeda E, Kasuga M, Yoshino G. A new family of lecithin : cholesterol acyltransferase deficiency. Domyakukoka (J Jpn Atheroscler Soc) 21: 232, 1993 (abstract in Japanese).

8) Hatch FT, Lees RS. Practical methods for plasma lipoprotein analysis. Adv Lipid Res 6: 1-68, 1968.

9) Cotgreave K, Lynes A. Quantitative analysis by thin-layer chromatography using a flame ionization detector. J Chromatogr 30: 117, 1967.

10) Mukherjee KD, Spaans H, Haahti E. New detector systems for thin-layer chromatography. J Chromatogr 61: 317, 1971.

11) Noble RP. Electrophoretic separation of plasma lipoproteins in agarose gel. J Lipid Res 9: 693, 1968.

12) Glomset JA, Nichols AV, Norum KR. Plasma lipoproteins in familial lecithin : cholesterol acyltransferase deficiency. J Clin Invest 52: 1078, 1973.

13) Forte T, Nichols AV. Application of electron microscopy to the study of 
plasma lipoprotein structure. Adv Lipid Res 10: 1, 1972.

14) Chen $\mathrm{CH}$, Albers JJ. Characterization of proteoliposomes containing apoprotein A-I: a new substrate for the measurement of lecithin : cholesterol acyltransferase activity. J Lipid Res 23: 680, 1982.

15) Albers JJ, Adolphson JL, Chen CH: Radioimmunoassay of human plasma lecithin : cholesterol acyltransferase. J Clin Invest 67: 141, 1981.

16) Assmann G, Schmitz G, Breuer HB Jr. Familial high density lipoprotein deficiency: Tangier disease. in: The Metabolic Basis of Inherited Disease, Scriver CR, Beaudet AL, Sly WS, Valle D, Eds. McGraw-Hill, Inc, New York, 1989, p. 1267.

17) Assmann G, von Eckardstein A, Funke H. Lecithin : cholesterol acyltransferase deficiency and fish-eye disease. Curr Opin Lipidol 2: 110, 1991.

18) Carlson LA, Philipson B. Fish-eye disease: a new familial condition with massive corneal opacities and dyslipoproteinemia. Lancet 2: 921, 1979.

19) Norum RA, Lakier JB, Goldstein S, et al. Familial deficiency of apolipoprotein A-I and C-III and precocious coronary-artery disease. N Engl J Med 306: 1513, 1982.

20) Schaefer EJ, Ordovas JM, Law SW, et al. Familial apoprotein A-I and CIII deficiency, variant II. J Lipid Res 26: 1089, 1985.

21) Frohlich J, Hoag G, McLeod R, et al. Hypoalphalipoproteinemia resembling fish eye disease. Acta Med Scand 221: 291, 1987.

22) Assmann G, Schmitz G, Funke H, von Eckardstein A. Apolipoprotein AI and HDL deficiency. Curr Opin Lipidol 1: 110, 1990.

23) Funke H, von Eckardstein A, Pritchard PH, Karas M, Albers JJ, Assmann G. A frameshift mutation in the human apolipoprotein A-I gene causes high density lipoprotein deficiency, partial lecithin : cholesterol acyltransferase deficiency, and corneal opacities. J Clin Invest 87: 371, 1991.

24) Sakuma M, Akanuma $Y$, Kodama T, et al. Familial plasma lecithin: cholesterol acyltransferase deficiency. Acta Med Scand 212: 225, 1982.

25) Kato K, Murayama N, Fujita T, et al. Familial lecithin : cholesterol acyltransferase deficiency - Report of a third Japanese family with two afflicted members. Nippon-Naikagakkai-Shi (J Jpn Soc Intern Med) 72: 1774, 1983 (in Japanese, abstract in English).

26) Midorikawa K, Satoh K, Abe K, et al. Familial LCAT deficiency - Case report. Domyakukoka (J Jpn Atheroscler Soc) 11: 1215, 1983 (in Japanese, abstract in English).

27) Takeuchi N, Matsumoto A, Bando S, et al. Lecithin : cholesterol acyltransferase deficiency. Taisha (Metabolism and Disease) 20: 81, 1983 (in Japanese).

28) Murano S, Shirai K, Saito $Y$, et al. Impaired intermediate-density lipoprotein triglyceride hydrolysis in familial lecithin : cholesterol acyltransferase (LCAT) deficiency. Scand J Clin Lab Invest 47: 775, 1987.

29) Takata K, Kajiyama G, Horiuchi I, et al. A new case of familial lecithin: cholesterol acyltransferase (LCAT) deficiency - paradoxical findings regarding LCAT mass and activity in 23 members of a family. Jpn J Med 28: 765, 1989.

30) Baba Y, Hamada F, Aozaki S, et al. A case of familial lecithin : cholesterol acyltransferase deficiency. Nippon-Jinzo-Gakkai-Shi (Jpn J Nephrol) 34: 309, 1992 (in Japanese, abstract in English).

31) Gotoda T, Yamada N, Murase T, et al. Differential phenotypic expression by three mutant alleles in familial lecithin : cholesterol acyltransferase deficiency. Lancet 338: 778, 1991.

32) Maeda E, Naka Y, Matozaki T, et al. Lecithin-cholesterol acyltransferase (LCAT) deficiency with a missense mutation in exon 6 of the LCAT gene. Biochem Biophys Res Commun 178: 460, 1991.

33) Bujo H, Kusunoki J, Ogasawara M, et al: Molecular defect in familial lecithin : cholesterol acyltransferase (LCAT) deficiency: a single nucleotide insertion in LCAT gene causes a complete deficient type of the disease. Biochem Biophys Res Commun 181: 933, 1991.

34) Klein H-G, Lohse P, Pritchard PH, Bojanovski D, Schmidt H, Brewer HB Jr. Two different allelic mutations in the lecithin-cholesterol acyltransferase gene associated with the fish eye syndrome. Lecithin-cholesterol acyltransferase (Thr123 $\rightarrow$ IIe) and lecithin-cholesterol acyltransferase (Thr347 $\rightarrow$ Met). J Clin Invest 89: 499, 1992.

35) Funke H, von Eckardstein A, Pritchard PH, et al. Genetic and phenotypic heterogeneity in familial lecithin : cholesterol acyltransferase (LCAT) deficiency. Six newly identified defective alleles further contribute to the structural heterogeneity in this disease. J Clin Invest 91: 677, 1993. 